Starch and its Derivatives

By J. A. Radley. (Monographs on Applied Chemistry, Vol. 11.) Pp. $x+346$. (London: Chapman and Hall, Ltd., 1940.) 22s. net.

F vital interest to the plant and animal physiologist and to the biochemist, starch has assumed a position of great importance also in applied chemistry and industry. To this latter domain this monograph properly belongs, and it is the latest of a series initiated by Dr. E. Howard Tripp with the intention of bringing together into one volume the mass of scattered literature, both old and new, which is of real value to the technologist in selected fields of chemical industry. This is a service which is widely acknowledged, and the present volume will be welcomed by many readers.

The subject of starch touches numerous and varied industries which are often exceedingly remote from one another; and the uses to which starch and its derivatives are put is some index of the very diversified character of the researches on this subject. The original literature is perhaps more voluminous than that of any other natural product. Those who have an interest in this field will therefore be grateful to the author for collecting into a single volume a body of knowledge on the manufacture and industrial applications of starch and the products derived from it.

Those sections devoted to dextrins and gums and to the general examination of starches, including their detection and chemical evaluation, are especially noteworthy, as are also the plates contributed by Mr. E. Young reproducing photomicrographs of starches of different origin.

The interests of the textile and paper industries, and the preparation of adhesives, receive more attention in this monograph than does the fermentation industry, which is a field too specialized for intensive treatment in a volume of this kind. A valuable and welcome feature is provided by the wealth of original references which are printed at the end of each chapter. It will be recognized that the merit of the different sections, treated so comprehensively, is a little unequal. That devoted to the structure of starch includes a review of some experimental data which have been superseded and could preferably have been exeluded; and generally one wishes that the author's selection of material had been more critical.

\section{A Handbook of Malaria Control}

By R. Svensson. (Published by the Shell Group of Oil Companies.) Pp. viii $+74+6$ plates. (London : Ross Institute of Tropical Hygiene, n.d.) n.p.

THIS useful little book by an assistant director of the Ross Institute of Tropical Medicine is primarily intended for laymen, especially planters, engineers and others, who have to undertake antimalarial work in the tropics, but it may also, as Sir Malcolm Watson remarks in the preface, be of use to medical practitioners. Within a small compass the book contains a generous quantity of valuable information, including not only an account of the different forms of malaria control but also a general survey of the malaria problem, notes on the various species of anophelines, laboratory equipment and methods, and a bibliography of recent British writers on the subject. The publication of the work has been undertaken by the Shell Group of Oil Companies.

\section{Organic Syntheses}

An Annual Publication of Satisfactory Methods for the Preparation of Organic Chemicals. Vol. 20. Pp. $\mathrm{v}+113$. (New York: John Wiley and Sons, Inc.; London : Chapman and Hall, Ltd., 1940.) 10s. $6 d$. net.

GOME forty substances are handled in this volume, $S$ of which one (sodium amide) is inorganic. Preparations of open-chain compounds include those of acetylacetone (by the boron trifluoride and sodium ethoxide methods), fumaryl chloride, tertiary butyl acetate (using acetyl chloride in presence of dry ether and magnesium), and the methyl esters of myristic and palmitic acids from the wax of the bayberry (Myrica cerifera). Among substances of biochemical importance, preparative details are given for the $d l$-forms of cysteic acid, serine, threonine, and valine; moreover, glucose is used as the basis of penta-acetyl- $d$-glucononitrile, $d$-arabinose, and 2,3,4,6tetramethyl- $d$-glucose. Some of the most interesting heterocyclic items are 1,2,3-benztriazole, dehydroacetic acid, 5,5-dimethylhydantoin, 5-nitroindazole, and picolinic acid hydrochloride. A useful selection of aromatic substances includes terephthaldehyde (from $p$-xylene), 2,2'-dinitrobiphenyl (from o-chloronitrobenzene and copper bronze), diphenylketene (from benzil monohydrazone), monoperphthalic acid, and mandelamide (from the acetone condensation product of mandelic acid, by ammonolysis with liquid ammonia in Dewar flasks). From the fact that the index covers volume 20 only, we infer hopefully that Collective Volume II, including annual volumes 10 to 19 , is now in course of preparation.

J. R.

\section{Plant Physiology}

By Meirion Thomas. Second edition. Pp. xii +596 . (London: J. and A. Churchill, Ltd., 1940.) $21 s$.

THE first edition of this valuable text-book was reviewed in NATURE of June 20, 1936, p. 1012 ; we are pleased to know that the book was so well received as to make a reprinting necessary in 1937 and now a second edition appears.

The general arrangement of subject-matter remains unaltered, though, of course, certain recent advances in plant physiology have been incorporated in the new edition. The chief of these include respiration, oxidation enzymes, the zymase-complex, absorption of solutes, translocation and storage of solutes in the cotton plant, mineral nutrition, composition of chloroplasts, reactions in photosynthesis and plant hormones.

Although certain deletions have been made, about a hundred pages have been added to the text and the price has been increased from 14s. to $21 s$. 